\title{
Retrospective Radiological and Clinical Assessments of 16 Patients with Tuberous Sclerosis
}

\author{
Gülay Güngör ${ }^{1}$, @ Olcay Güngör² \\ ${ }^{1}$ Department of Radiology, Sutcu Imam University Faculty of Medicine, Kahramanmaras, Turkey \\ ${ }^{2}$ Department of Pediatric Neurology, Necip Fazıl City Hospital, Kahramanmaras, Turkey
}

\begin{abstract}
Introduction: Tuberous sclerosis (TSC) is a multisystem, autosomal dominant disorder with a wide clinical spectrum. The aim of the present study was to review the clinical, radiological, and laboratory findings of our TSC cases in a retrospective manner and to compare them with the current literature.

Methods: The clinical and radiological features of 16 patients diagnosed with TSC at Sütçü Imam University, Faculty of Medicine, Pediatric Neurology Outpatient Clinic were retrospectively assessed.

Results: A total of 16 patients with a diagnosis of TSC were included in the study. The study included 9 (56.2\%) male and 7 (43.7\%) female patients. Of the 16 patients, 9 (56.2\%) presented with convulsions, 4 (25\%) with body rash, 2 (12.5\%) with cardiac rhabdomyoma diagnosed at the newborn period, and 1 (6.25\%) with perinatal asphyxia. Hypopigmented skin lesions were detected in all patients (100\%). The most common finding on brain magnetic resonance imaging (MRI) was periventricular subependymal nodules (SNs) ( $n=12,75 \%)$. In addition to the central nervous system and skin findings, 3 (18.7\%) patients had cardiac involvement, and 1 (6.2\%) patient had renal involvement. Three (18.7\%) patients were detected with diffuse developmental delay, and 6 (37.5\%) patients were detected with mental retardation.

Discussion and Conclusion: In line with the current literature, convulsions, hypopigmented skin lesions, mental retardation, and SNs on brain MRI were the most common signs.

Keywords: Child; epilepsy; tuberous sclerosis.
\end{abstract}

$\mathrm{T}$ uberous sclerosis (TSC) is a "neurocutaneous" disorder affecting a variety of systems. It was first described by Friedrich Daniel von Recklinghausen in 1862 in an infant with cardiac "myomas" and sclerotic areas in the brain tissue. Thereafter, in 1880, Bourneville described the condition more in depth. Since then, the term TSC was used to describe the condition ${ }^{[1]}$. Mental retardation, convulsions, and adenoma sebaceum form the diagnostic triad of the condition. TSC has an incidence of 1 in 6000-10.000 births ${ }^{[1,2]}$. It shows an autosomal dominant trait with a high rate of self-mutations. The most notable features of the disorder are glial-neuronal and retinal hamartomas, subependymal giant cell tumors (GCTs), cardiac rhabdomyomas, renal and non-renal angiomyolipomas (AMLs), and pulmonary lymphangioleiomyomatosis [3]. Clinically, its course is characterized by resistant epilepsy, mental retardation, behavioral problems, and skin lesions ${ }^{[4]}$. The aim of the present study was to review the clinical and radiological findings of our TSC cases and to compare them with the current literature. We also aimed to stress the importance of a multidisciplinary approach at the diagnostic and therapeutic stages of these patients.

Correspondence (İletişim): Olcay Güngör, M.D. Necip Fazil Sehir Hastanesi, Pediatrik Noroloji Bolumu, Kahramanmaras, Turkey Phone (Telefon): +90 5065020439 E-mail (E-posta): drolcaygungor@gmail.com

Submitted Date (Başvuru Tarihi): 16.12.2018 Accepted Date (Kabul Tarihi): 03.03.2019

Copyright 2019 Haydarpaşa Numune Medical Journal

OPEN ACCESS This is an open access article under the CC BY-NC license (http://creativecommons.org/licenses/by-nc/4.0/) 


\section{Materials and Methods}

A total of 16 patients who presented to the Sütçü İmam University, Faculty of Medicine, Pediatric Neurology Outpatient Clinic and who were diagnosed with TSC between 2008 and 2015 were enrolled in the study. The study was approved by the Sütçü İmam University Medical Ethical Committee (No.: 136, date: 09/27/2017). Age, sex, family history, neurological and systemic examinations, electroencephalography, brain magnetic resonance imaging (MRI), cranial computerized tomography (CT), abdominal ultrasonography, electrocardiography, echocardiography, and ophthalmological findings were evaluated. TSC was diagnosed based on the clinical and imaging findings. Epilepsy was diagnosed based on the seizure definition provided by a patient relative, electroencephalogram findings, and the International League Against Epilepsy classification ${ }^{[5]}$. Data were analyzed using SPSS 20.0 (SPSS Inc., Chicago, IL, USA) software for statistical analyses. Descriptive statistics were expressed as number $(n)$, percentage (\%), and mean \pm standard deviation.

\section{Results}

The medical records of 16 patients diagnosed with TSC were included in our study. Among the 16 patients enrolled in the study, 9 (56.2\%) were men, and 7 (43.7\%) were women. The mean age at admission of the patients was 31.1 (3-156) months. Three (18.7\%) patients had a family history of TSC, and 3 (18.7\%) patients had a history of parental consanguineous marriage. Nine (56.2\%) cases were diagnosed in the first year of life. All patients had hypomelanotic macules. Of the 16 patients, facial angiofibroma was observed in 5 (32.2\%), and shagreen patches were observed in $3(18.7 \%)$ (Fig. 1). The most common presenting symptom was convulsions. Nine $(56.2 \%)$ cases presented with convulsions, and $4(25 \%)$ cases presented with skin lesions. Of the nine patients with convulsions,
3 (33.3\%) had infantile spasm, and $6(66.6 \%)$ had other seizure types. Two (12.5\%) patients had resistant epilepsy. Clinical findings are shown in Table 1. Some patients with TSC had periventricular subependymal nodules (SNs) (Fig. 2a) and cortical tubers (Fig. 2b) on MRI. Calcified SNs were seen on CT images (Fig. 2C). The most common findings on MRI are shown in Table 2.

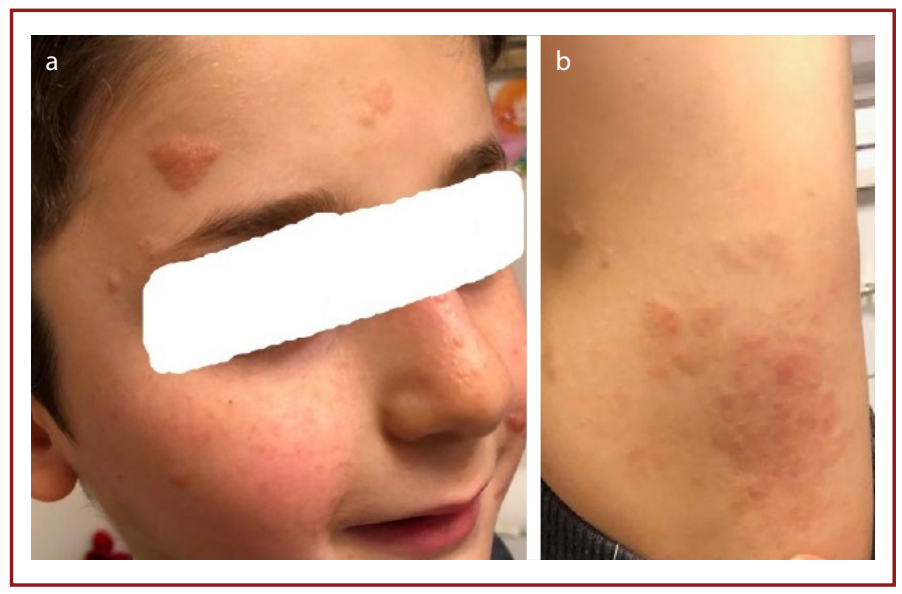

Figure 1. Clinical manifestations: facial angiofibromas (a), shagreen patch (b).

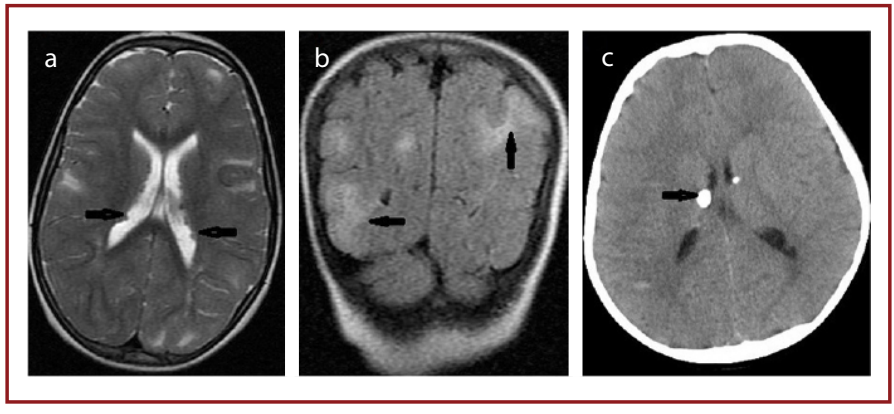

Figure 2. Axial T2 weighted (a) image shows low-signal subependymal nodules (black arrow) with periventricular placement and hyperintense cortical tuberosclerosis. In coronal FLAIR (b) image, cortical hyperintense tuber (black arrow) is clearly selected. Axial CT image (c) shows calcified subependymal nodule appearance (black arrow).

Table 1. Clinical features of patients with tuberous sclerosis

\begin{tabular}{|c|c|c|c|c|c|c|c|}
\hline & Our study & $\begin{array}{l}\text { İncecik } \\
\text { et al. [8] }\end{array}$ & $\begin{array}{l}\text { Rubilar } \\
\text { et al. [14] }\end{array}$ & $\begin{array}{c}\text { Almoberak } \\
\text { et al. }{ }^{[10]}\end{array}$ & $\begin{array}{l}\text { Wilbur } \\
\text { et al. [11] }\end{array}$ & $\begin{array}{l}\text { Sing Au } \\
\text { et al. [12] }\end{array}$ & $\begin{array}{c}\text { Saltık } \\
\text { et al. }{ }^{[13]}\end{array}$ \\
\hline Hypopigmented skin lesions (\%) & 100 & 100 & 100 & 100 & 77 & 89.1 & 95.2 \\
\hline Facial angiofibroma (\%) & 31.2 & 47.3 & 47.6 & 17 & 43 & 60.1 & 66.6 \\
\hline Shagreen patches (\%) & 18.7 & 15.7 & 23.8 & 13.6 & 25 & 38.9 & 23.8 \\
\hline Mental retardation (\%) & 23.5 & 68.4 & - & 23.9 & 33 & 46.5 & - \\
\hline Convulsion (\%) & 56.2 & 89.1 & 48.7 & 68.2 & 91 & 74.8 & 42.8 \\
\hline Rhabdomyoma (\%) & 18.7 & 21 & 47.6 & 18.2 & 35 & 46.2 & 14.3 \\
\hline Renal involvement (AML) (\%) & 6.2 & 5.2 & 16.7 & 26.1 & 43 & 46.6 & 23.8 \\
\hline
\end{tabular}


Table 2. Radiological findings of patients with tuberous sclerosis

\begin{tabular}{lcccc}
\hline & Our study & $\begin{array}{c}\text { incecik } \\
\text { et al. }{ }^{[8]}\end{array}$ & $\begin{array}{c}\text { Rubilar } \\
\text { et al. }{ }^{[14]}\end{array}$ & $\begin{array}{c}\text { Saltık } \\
\text { et al. [13] }\end{array}$ \\
\hline $\begin{array}{l}\text { Periventricular } \\
\text { subependimal }\end{array}$ & 75 & 89.4 & 40 & 85.7 \\
$\begin{array}{l}\text { nodule (\%) } \\
\text { Cortical tubers (\%) }\end{array}$ & 56.2 & 42.1 & 35 & 95.2 \\
$\begin{array}{l}\text { Giant cell astrocytoma } \\
\text { (suspicious) (\%) }\end{array}$ & 6.2 & 10.5 & 5 & 23.8 \\
\hline
\end{tabular}

\section{Discussion}

Since TSC involves multiple systems, it has a variable clinical presentation. Approximately $30 \%$ of TSC cases are inherited in an autosomal dominant fashion, whereas approximately $70 \%$ of cases emerge as a result of spontaneous mutations ${ }^{[6,7]}$. The mean age at diagnosis of the patients was 5 years. Neurological involvement occurs in the form of convulsions, mental retardation, autism spectrum disorder, or behavioral disorders ${ }^{[8,9]}$. Convulsions start in the first year of life and are the most common cause of presentation. The typical types of convulsion are focal seizures and infantile spasms, with the latter being reported to have a prevalence of $10 \%-25 \%$ [9]. In our study, 9 (56.2\%) out of 16 patients presented with convulsions. The prevalence of seizure as one of the initial TSC manifestations was lower than those recently reported from the studies published by Almoberak et al., ${ }^{[10]}$ Wilbur et al., ${ }^{[4]}$ Sing Au et al., ${ }^{[7]}$ and Incecik et al. ${ }^{[8]}$ at $68.2 \%, 91 \%, 74.8 \%$, and $89.1 \%$, respectively. Similar results were found in the studies by Saltuk et al. ${ }^{[11]}$ at $42.8 \%$ and Rubilar et al. ${ }^{[12]}$ at $48.7 \%$. Such a difference is likely to be due to the inadequate diagnosis and/or inadequate reporting of signs and symptoms as a result of insufficient diagnostic and/or data recording (Table 1).

Ninety percent of children with TSC may have neuropsychiatric disorders (attention deficit/hyperactivity disorder and mental illness) ${ }^{[2,13]}$. In the present study, 9 (56.2\%) patients suffered mental retardation, and 1 (6.2\%) patient had hyperactivity.

In accordance with the literature, control of seizure activity was difficult in patients with TSC ${ }^{[8]}$. In one patient with resistant epilepsy persisting despite antiepileptics, everolimus was started, which provided a reduction of $>50 \%$ in seizure activity.

In TSC, approximately $90 \%$ of skin lesions are hypopigmented skin lesions. These are ovoid or leaf-shaped and of varying sizes and most commonly develop in the trunk and extremities. Lesions typically exist at birth and be- come more pronounced in the first few years of life. They are more easily detected using a Wood lamp ${ }^{[14]}$. All of our patients had hypopigmented skin lesions, and four of them presented for examination of those lesions. Adenoma sebaceum, one of the skin lesions in TSC, appears as pink or red papules with angiofibromatous characteristics and is distributed on the nose with the form of a butterfly rash. It typically develops between the ages of 1 and 4 years. Our study found a prevalence of $31.2 \%(n=5)$, which was in agreement with the previous reports in the literature. Shagreen patches are rarer in TSC. These lesions are usually found in the lumbosacral or gluteal region $[2,14]$. In our study, 2 (12.5\%) patients had these patches. Rubilar et al., ${ }^{[12]}$ Wilbur et al., ${ }^{[4]}$ and Sing Au et al. ${ }^{[7]}$ found the frequency of adenoma sebaceum to be $47.6 \%, 43 \%$, and $60.1 \%$, respectively. Since the number of cases in our study is low, we think that the frequency of adenoma sebaceum is lower than that in the previous studies.

Patients with TSC typically have structural brain anomalies, cortical tubers, SNs, and subependymal GCTs. Cortical tubers are found in at least $80 \%$ of patients. These are made up of abnormal neurons and glial cells ${ }^{[15]}$. They are areas of focal cortical dysplasia that remain unchanged over time. However, cortical tubers are associated with the development of epilepsy. MRI is more useful than $C T$ for the detection of cortical tubers. Cortical tubers usually have increased signal intensity on T2-weighted images but decreased signal intensity on T1-weighted images. Calcification and central cystic degeneration can sometimes occur. $\mathrm{CT}$ is a useful tool for the detection of $\mathrm{SN}$, since it is associated with calcification far more commonly $(88 \%)$ than cortical tubers. Unenhanced CT typically depicts multiple small foci with dense calcification along both lateral ventricles. On MRI, SNs appear hyperintense on T1-weighted images and iso- to hyperintense on T2-weighted images. White matter abnormalities of TSC include (1) superficial white matter abnormalities associated with cortical tubers, (2) radial white matter bands, and (3) cyst-like white matter lesions ${ }^{[16]}$. On cranial MRI findings, cortical tuber was found in 20 (95.2\%) patients, SN was found in 18 (85.7\%) patients, and astrocytoma was found in $5(23.8 \%)$ patients [11]. In our study, cortical tubers were detected in 9 (56.2\%) patients. SNs are found in up to $90 \%$ of patients; they are calcified and intraventricular protrusions composed of abnormal cells in the lateral ventricle neighboring the caudate nucleus (Fig. 2c) ${ }^{[15]}$. Incecik et al. ${ }^{[8]}$ found these nodules in $89.4 \%$ of their patients. In the present study, $75 \%$ of patients had SN. GCTs are intraventricular glioneuronal tumors ${ }^{[8]}$. They are found in the caudothalamic sulcus in 
the vicinity of the foramen of Monro. Subependymal GCTs are found in $10 \%-20 \%$ of patients, and these slowly growing benign tumors may cause obstruction $[2,15,17]$. In our series, their prevalence was $6.2 \%$. Rubilar et al. ${ }^{[12]}$ found similar rates with our study. The number of patients with these tumors may increase as the duration of follow-up is prolonged in the future. The most common cardiac finding of TSC is rhabdomyoma, which may be detected by ultrasonography in at least $50 \%$ of newborns between 20 and 30 weeks of gestation. Patients may be asymptomatic but may also present with severe heart failure or, owing to a compression of the cardiac conduction system, arrhythmia $[1,2,18]$. Rhabdomyomas in our patients did not produce any symptoms, and echocardiographic examination revealed no form of arrhythmia.

The most common renal lesions in TSC are AML and renal cysts. AML exists in approximately $50 \%-80 \%$ of affected patients. They are usually asymptomatic, but produce symptoms depending on lesion grade ${ }^{[8,19]}$. One of our patients with renal involvement had microscopic hematuria. A renal ultrasonography showed AML in the left kidney.

Children with TSC need to undergo renal ultrasonography every 2 or 3 years before puberty and every year thereafter. Renal signs usually develop after the age of 10 years $[2,8,20]$. Our patient with AML was 9 years old. Although the incidence rate in the literature was different, the frequency of AML in our study was lower [10,11]. Chromosomal studies in TSC identified two genes. Of the two genes, TSC1 is located on the $9^{\text {th }}$ chromosome $(9 q$ 34.3-hamartin), and TSC2 is located on the $16^{\text {th }}$ chromosome (16p13.3-tuberin) ${ }^{[6,7]}$. We did not perform genetic testing in our patients. Having an autosomal dominant trait, TSC may lack a family history in three-fourths of cases ${ }^{[6,7,20]}$. We identified TSC in any family member at a rate of $18.7 \%$. Therefore, family screening should be definitely performed when a patient is diagnosed with TSC. The screening should necessarily involve a physical examination for skin lesions, fundoscopic examination, a brain MRI, and an abdominal ultrasonogram. After TSC is diagnosed, genetic counseling should be provided to prevent new cases from developing.

\section{Limitations}

Our study has limitations. The main limitation of the study was its retrospective design. Therefore, we had no option for selecting diagnostic approaches and imaging studies. Another important limitation of our study was its small sample size.

\section{Conclusion}

In conclusion, TSC is a multiorgan genetic disorder primarily affecting the brain, kidneys, heart, skin, and lungs. Considering its multisystem involvement, it may sometimes cause life-threatening complications including seizures, such as infantile spasms, and renal AML. As some of these signs and symptoms may emerge with aging, we think that it would be useful to repeat studies, performed the time of diagnosis, at regular intervals.

Ethics Committee Approval: This study was approwed by the Sütçü İmam Üniversity Medical Committee's Local Ethics Committee No:136 date: September 27, 2017.

Peer-review: Externally peer-reviewed.

Authorship Contributions: Concept: G.G.; Design: G.G., O.G.; Data Collection or Processing: O.G., G.G.; Analysis or Interpretation: O.G.; Literature Search: G.G., O.G.; Writing: G.G.

Conflict of Interest: None declared.

Financial Disclosure: The authors declared that this study received no financial support.

\section{References}

1. Roach ES. Applying the Lessons of Tuberous Sclerosis: The 2015 Hower Award Lecture. Pediatr Neurol 2016;63:6-22.

2. Northrup $\mathrm{H}$, Krueger DA; International Tuberous Sclerosis Complex Consensus Group. Tuberous sclerosis complex diagnostic criteria update: recommendations of the 2012 linternational Tuberous Sclerosis Complex Consensus Conference. Pediatr Neurol 2013;49:243-54. [CrossRef]

3. Randle SC. Tuberous Sclerosis Complex: A Review. Pediatr Ann 2017;46:e166-e171. [CrossRef]

4. Wilbur C, Sanguansermsri C, Chable H, Anghelina M, Peinhof $\mathrm{S}$, Anderson K, et al. Manifestations of Tuberous Sclerosis Complex: The Experience of a Provincial Clinic. Can J Neurol Sci 2017;44:35-43. [CrossRef]

5. Fisher RS, Cross JH, French JA, Higurashi N, Hirsch E, Jansen $\mathrm{FE}$, et al. Operational classification of seizure types by the International League Against Epilepsy: Position Paper of the ILAE Commission for Classification and Terminology. Epilepsia 2017;58:522-530. [CrossRef]

6. Jones AC, Shyamsundar MM, Thomas MW, Maynard J, Idziaszczyk S, Tomkins $S$, et al. Comprehensive mutation analysis of TSC1 and TSC2-and phenotypic correlations in 150 families with tuberous sclerosis. Am J Hum Genet 1999;64:1305-15.

7. Au KS, Williams AT, Roach ES, Batchelor L, Sparagana SP, Delgado MR, et al. Genotype/phenotype correlation in 325 individuals referred for a diagnosis of tuberous sclerosis complex in the United States. Genet Med 2007;9:88-100. [CrossRef]

8. Incecik F, Herguner O, Ozcan K, Altunbasak A. Tuberosklerozlu 19 olgunun geriye dönük olarak değerlendirilmesi. Turk Ped Ars 2006;41:156-60. 
9. Hancock E, Osborne JP. Vigabatrin in the treatment of infantile spasms in tuberous sclerosis: literature review. J Child Neurol 1999;14:71-4. [CrossRef]

10. Almobarak S, Almuhaizea M, Abukhaled M, Alyamani S, Dabbagh O, Chedrawi A, et al. Tuberous Sclerosis Complex: Clinical Spectrum and Epilepsy: A Retrospective Chart Review Study. TransI Neurosci 2018;9:154-160. [CrossRef]

11. Saltık S, Karatoprak EY, Taşel B. Characteristics and the clinical prognosis of epilepsy in patients with a diagnosis of tuberous sclerosis complex. Turk Arch Ped 2013;123-30. [CrossRef]

12. Rubilar C, López F, Troncoso M, Barrios A, Herrera L. Clinical and genetic study patients with tuberous sclerosis complex. Rev Chil Pediatr 2017;88:41-49.

13. de Vries PJ, Whittemore VH, Leclezio L, Byars AW, Dunn D, Ess KC, et al. Tuberous sclerosis associated neuropsychiatric disorders (TAND) and the TAND Checklist. Pediatr Neurol 2015;52:25-35. [CrossRef]

14. Jacks SK, Witman PM. Tuberous Sclerosis Complex: An Update for Dermatologists. Pediatr Dermatol 2015;32:563-70. [CrossRef]

15. Roth J, Roach ES, Bartels U, Jóźwiak S, Koenig MK, Weiner $\mathrm{HL}$, et al. Subependymal giant cell astrocytoma: diagnosis, screening, and treatment. Recommendations from the International Tuberous Sclerosis Complex Consensus Conference 2012. Pediatr Neurol 2013;49:439-44. [CrossRef]

16. von Ranke FM, Faria IM, Zanetti G, Hochhegger B, Souza AS Jr, Marchiori E. Imaging of tuberous sclerosis complex: a pictorial review. Radiol Bras 2017;50:48-54. [CrossRef]

17. Goh S, Butler W, Thiele EA. Subependymal giant cell tumors in tuberous sclerosis complex. Neurology 2004;63:1457-61.

18. Hinton RB, Prakash A, Romp RL, Krueger DA, Knilans TK; International Tuberous Sclerosis Consensus Group. Cardiovascular manifestations of tuberous sclerosis complex and summary of the reviseddiagnostic criteria and surveillance and management recommendations from the InternationalTuberous Sclerosis Consensus Group. J Am Heart Assoc 2014;3:e001493.

19. Kingswood JC, Bissler JJ, Budde K, Hulbert J, Guay-Woodford L, Sampson JR, et al. Review of the Tuberous Sclerosis Renal Guidelines from the 2012 Consensus Conference: Current Data and Future Study. Nephron 2016;134:51-8. [CrossRef]

20. Caban C, Khan N, Hasbani DM, Crino PB. Genetics of tuberous sclerosis complex: implications for clinical practice. Appl Clin Genet. $2016 ; 10: 1-8$. [CrossRef] 